\title{
1. Introduction to The Interface between Intellectual Property and Investment Law
}

In recent years, there have been a number of high-profile claims brought by corporate actors against states challenging measures relating to intellectual property before investment tribunals. Both developed countries (e.g. Australia and Canada) and developing countries (e.g. Panama and Uruguay) have been confronted with such claims in the last decade. ${ }^{1}$ These developments have led to increased scrutiny of the interface between intellectual property and investment law. ${ }^{2}$ However, it should be noted that the relationship between intellectual property and investment law predates these recent developments. For instance, intellectual property has always been a key feature of bilateral investment treaties (BITs). In the first ever BIT, the 1959 BIT between West Germany and Pakistan, reference is made to 'patents and technical knowledge' in the definition of investment. ${ }^{3}$ Furthermore, even though the recent claims before investment tribunals have involved traditional and more popular forms of intellectual property rights such as patent rights and trademarks, there are

1 See, Philip Morris Asia Ltd v Australia, PCA Case No. 2012-12, Award on Jurisdiction and Admissibility (17 December 2015); Philip Morris Brands Sarl \& Others v Uruguay, ICSID Case No. ARB/10/7, Award (8 July 2016); Eli Lilly v Canada, Case No. UNCT/14/2, Final Award (16 March 2017); Bridgestone Licensing Services, Inc v Republic of Panama, ICSID Case No. ARB/16/34, Award (14 August 2020).

2 See for instance, Lukas Vanhonnaeker, Intellectual Property Rights as Foreign Direct Investments: From Collision to Collaboration (Edward Elgar, 2015); Metka Potočnik, Arbitrating Brands: International Investment Treaties and Trade Marks (Edward Elgar, 2019); Christophe Geiger (ed.), Research Handbook on Intellectual Property and Investment Law (Edward Elgar, 2020).

Article 8(1)(a) of the West Germany-Pakistan BIT of 1959 provides that, '[t]he term "investment" shall comprise capital brought into the territory of the other Party for investment in various forms in the shape of assets such as foreign exchange, goods, property rights, patents and technical knowledge. The term "investment" shall also include the returns derived from and ploughed back into such "investment".' 
a number of older investment disputes involving other forms of intellectual property rights such as know-how and goodwill. ${ }^{4}$

Nevertheless, some of the criticisms and concerns recently expressed about the interface between intellectual property and investment law are understandable if one considers the fact that some of the recent cases have involved challenges against intellectual property measures aimed at addressing public health issues, such as the consumption of tobacco products. This explains why some intellectual property scholars have expressed concerns about the potential impact that the investment law regime can have on the intellectual property policy space available to states. ${ }^{5}$ It has even been suggested that the objectives of the international intellectual property law regime may not be compatible with the objectives of the international investment law regime. ${ }^{6}$ It seems that an implicit assumption that underlies some of these criticisms and concerns is

4 See generally, Holiday Inns S.A. and others v Morocco, Case No, ARB/72/1, Decision on Jurisdiction (12 May 1974); Amco Asia Corporation and others $v$ Republic of Indonesia Case No. ARB/81/1, Decision on Application for Annulment of the Award (16 May 1986); Salini Construttori SpA and Italstrade SpA v Kingdom of Morocco, Case No. ARB/00/4, Decision on Jurisdiction (23 July 2001); Patrick Mitchell $v$ Democratic Republic of Congo, Case No. ARB/99/7, Decision on the Application for Annulment of the Award (1 November 2006).

5 Henning Grosse Ruse-Khan, 'Protecting Intellectual Property Rights under BITs, FTAs and TRIPS: Conflicting Regimes or Mutual Coherence?' in Chester Brown and Kate Miles, Evolution in Investment Treaty Law and Arbitration (Cambridge University Press, 2011) pp 485-515; Cynthia Ho, 'A Collision Course between TRIPS Flexibilities and Investor-State Proceedings’ (2016) 6 UC Irvine Law Review, 101; James Gathii and Cynthia Ho, 'Regime Shift of IP Lawmaking and Enforcement from WTO to the International Investment Regime' (2017) 18(2) Minnesota Journal of Law, Science \& Technology, 427; Peter Yu, 'The Investment-Related Aspects of Intellectual Property Rights' (2017) 66(3) American University Law Review 829; Henning Grosse Ruse-Khan, 'Protecting Intellectual Property through Trade and Investment Agreements: Concepts, Norm-setting and Dispute Settlement' in Christophe Geiger (ed.), Research Handbook on Intellectual Property and Investment Law (Edward Elgar, 2020) p 11.

6 See, Susy Frankel, 'Interpreting the Overlap of International Investment and Intellectual Property Law’ (2016) 19 Journal of International Economic Law, 121. Susy Frankel, 'The Object and Purpose of Mingling Intellectual Property, Trade and Investment' in Christophe Geiger (ed.), Research Handbook on Intellectual Property and Investment Law (Edward Elgar, 2020) pp 48-49 (observing that, '[s]ubstantive intellectual property treaties are predominately about creating obligations for states to provide minimum standards of protection, in their national law, and allowing for exceptions to those obligations within certain rules ... International investment agreements, which either take the form of bilateral investment treaties (BITs) or chapters in free trade agreements (FTAs), are directed towards protecting investors' property when they make investments ... The goals of intellectual property law and investment law, while they overlap are certainly not co-extensive'). 
the view that investment tribunals cannot or will not take into account the rules of international intellectual property law when resolving investment disputes involving intellectual property rights. ${ }^{7}$ This implicit assumption is, however, questioned in this book.

Bearing in mind all the concerns expressed in the existing literature regarding the interface between international intellectual property law and international investment law, the central question that this book seeks to answer is this: how should the terms and standards of protection contained in investment treaties be interpreted and applied in investment disputes involving intellectual property rights? In answering this key question, the focus of this book is limited to those aspects of international investment law that have actually been litigated before investment tribunals in investment disputes involving intellectual property rights. These are jurisdictional issues regarding the question of whether intellectual property should be defined as an investment, ${ }^{8}$ and the application of two standards of protection (i.e. fair and equitable treatment and expropriation). ${ }^{9}$ Thus, while other issues such as the interpretation and appli-

7 See, Henning Grosse Ruse-Khan, 'Protecting Intellectual Property through Trade and Investment Agreements: Concepts, Norm-setting and Dispute Settlement' in Christophe Geiger (ed.), Research Handbook on Intellectual Property and Investment Law (Edward Elgar, 2020) pp 45 (observing that, '[b]y protecting IP rights as an investment asset, international investment law makes a whole new (or perhaps better: distinct) set of commitments from another area of global norm-setting available to IP owners. From among these commitments, the principal tool for expansion is [the investor-state dispute settlement (ISDS) system] as a litigation mechanism that directly benefits IP owners once they qualify as investors ... investment protection for IP rights is essentially enlarged through ISDS as a private dispute settlement tool with public consequences'). In addition, Cynthia Ho seems to imply that investment tribunals are not judiciously positioned to take the rules of international intellectual property law into account when resolving investment disputes. See, Cynthia Ho, 'The Intersection of ISDS and TRIPS Flexibilities' in Christophe Geiger (ed.), Research Handbook on Intellectual Property and Investment Law (Edward Elgar, 2020) p 207 (contending that, '[a]lthough some commentators have asserted that initial disputes suggest that such flexibilities are preserved, this chapter suggests that TRIPS flexibilities remain threatened by the continued existence of ISDS. Why? The short answer is that these initial decisions fundamentally indicate that investor-state tribunals consider it appropriate to address issues covered by TRIPS/WTO. Notably, the WTO has its own dispute settlement mechanism that was intended to be the exclusive venue for addressing TRIPS issues, and also has more inherent balance between private and public interests than most international agreements permitting ISDS').

8 See for instance, Philip Morris v Uruguay, ICSID Case No. ARB/10/7, Decision on Jurisdiction (2 July 2013); Bridgestone Licensing Services, Inc v Republic of Panama, ICSID Case No. ARB/16/34, Decision on Expedited Objections (13 December 2017).

9 See for instance, Philip Morris Brands Sarl \& Others v Uruguay, ICSID Case No. ARB/10/7, Award (8 July 2016); Eli Lilly v Canada, Case No. UNCT/14/2, Final 
cation of the national treatment and most-favoured-nation treatment standards are equally important when examining the interface between intellectual property law and investment law, they are not considered in this book as they have not been directly addressed in any investment dispute in the context of the interface between intellectual property law and investment law as at the time of writing. ${ }^{10}$

This book proposes that an intertextual approach should inform the interpretation and application of investment treaties in investment disputes involving intellectual property rights. The theoretical framework for this intertextual approach is laid out in chapter two of this book. Importantly, as explained in chapter three, this intertextual approach entails incorporating the rules of international intellectual property law into the interpretation and application of investment treaties in investment disputes involving intellectual property rights. This would ensure that in defining intellectual property as an investment (chapter four) and in the interpretation and application of the fair and equitable treatment standard (chapter five) and the expropriation standard (chapter six), the objectives and goals of both the international intellectual property law regime and the international investment law regime are synchronised. An intertextual approach would equally help to preserve the intellectual property policy space of host states. As will be demonstrated in this book, investment tribunals can and should adopt an intertextual approach when resolving investment disputes that involve intellectual property rights.

Award (16 March 2017); Bridgestone v Panama, ICSID Case No. ARB/16/34, Award (14 August 2020).

10 For a critical discussion of the national treatment and most-favoured-nation treatment standards in the context of the interface between international intellectual property law and international investment law, see: Lukas Vanhonnaeker, 'The Relevance of National Treatment and Most Favoured Nation in the Context of Intellectual Property and Investment Disputes' in Christophe Geiger (ed.), Research Handbook on Intellectual Property and Investment Law (Edward Elgar, 2020) p 137; Lukas Vanhonnaeker, Intellectual Property Rights as Foreign Direct Investments: From Collision to Collaboration (Edward Elgar, 2015) pp 79-100. 